\title{
Bladder Cancer pT2b TNM Finding v7
}

National Cancer Institute

\section{Source}

National Cancer Institute. Bladder Cancer pT 2b TNM Finding v7. NCI Thesaurus. Code C89354.

Bladder cancer with tumor invading the deep muscularis propria (outer half). (from AJCC 7th Ed.) 